\title{
Correction to: A sliding mode contact electrification based triboelectric-electromagnetic hybrid generator for small-scale biomechanical energy harvesting
}

Venkateswaran Vivekananthan, Woo Joong Kim, Nagamalleswara Rao Alluri, Yuvasree Purusothaman, K. S. Abisegapriyan and Sang-Jae Kim*

\section{Correction to: Micro and Nano Syst Lett (2019) 7:14 https://doi.org/10.1186/s40486-019-0093-6}

Unfrotunately, the original version of the article [1] contained an error in Funding section. It has been brought to our attention by the authors that the funding year was inadvertently published as 2019, instead it should be 2018. The correct Funding section is given below.

\section{Funding}

The research was supported by the 2018 scientific program funded by Jeju National University.
Reference

1. Vivekananthan V, Kim WJ, Alluri NR, Purusothaman Y, Abisegapriyan KS, Kim SJ (2019) A sliding mode contact electrification based triboelectricelectromagnetic hybrid generator for small-scale biomechanical energy harvesting. Micro and Nano Syst Lett 7:14. https://doi.org/10.1186/s4048 6-019-0093-6

\section{Publisher's Note}

Springer Nature remains neutral with regard to jurisdictional claims in published maps and institutional affiliations.

Published online: 01 February 2020

The original article can be found online at https://doi.org/10.1186/s4048 6-019-0093-6.

*Correspondence: kimsangj@jejunu.ac.kr

Nanomaterials and Systems Laboratory, Department of Mechatronics

Engineering, Jeju National University, Engineering Building No:-4, D-130,

Ara-1-Dong, Jeju-Si, Jeju-Do 63243, South Korea the source, provide a link to the Creative Commons licence, and indicate if changes were made. The images or other third party material in this article are included in the article's Creative Commons licence, unless indicated otherwise in a credit line to the material. If material. is not included in the article's Creative Commons licence and your intended use is not permitted by statutory regulation or exceeds the permitted use, you will need to obtain permission directly from the copyright holder. To view a copy of this licence, visit http://creativecommons.org/licenses/by/4.0/ 